\title{
Influence of the absorbed dose of radiation radiation on the destruction of polypropylene, depending on the location of the sample to the electron radiator
}

\author{
(C) Elvina R. Rakhmatullina, Rezeda Yu. Galimzyanova, and Maria S. Lisanevich* ${ }^{+}$ \\ Faculty of technology of light industry and fashion. Kazan National Research Technological University. \\ Karl Marx St., 68. Kazan, 420015. Russia. Phone: +7 (843) 231-43-36.E-mail: lisanevichm@gmail.com
}

\begin{abstract}
*Supervising author; ${ }^{+}$Corresponding author
\end{abstract}
Keywords: polypropylene, radiation sterilization, radiation resistance, medical clothing and disposable underwear, destruction, aging of the material, thermal oxidation.

\begin{abstract}
Currently, polypropylene is one of the most common polymers in the world. Due to its resistance to high temperatures, strength and density, it has found very wide application in the field of medicine. Polypropylene produces medical devices, pharmaceutical packaging, containers, suture threads. But a special place is occupied by non-woven materials based on polypropylene: surgical underwear, surgical gowns. As you know, to sterilize these products using ionizing radiation, which is the most effective of all methods. However, it leads to the destruction of polypropylene, as a result of which its physical and mechanical properties deteriorate. It is also known that the dose of radiation can vary depending on the location of the product in the box. Thus, materials can be degraded to varying degrees depending on the location in the box from the electronic emitter. As the object of study was selected: PP 1562R polypropylene produced by $O A O$ Nizhnekamskneftekhim. It has been established that the location of polypropylene samples upon irradiation has little effect on the degree of their destruction.
\end{abstract}

\section{References}

[1] The use of polypropylene in medicine [Electronic resource]. URL: $\mathrm{http}: / / \mathrm{www} . v 0 l o t . r u / a r t i c l e s / d e t a i l s / 46 . h t m$. (date of access - 07.03.2016)

[2] D.J. Lyman. Polymers in medicine. per. from English. Moscow: Second-hand bookseller. 1969. 240p. (russian)

[3] Polymers in medicine [Electronic resource]. URL: http://mplast.by/encyklopedia/polimeryi-v-meditsine/. (date of access - 09.03.2016)

[4] Infectious complications in surgery: antibacterial prophylaxis and therapy. Consilium Medicum 02.2002, 4/N B.S. Briskin.

[5] V.K. Gostishchev, N.A. Semina, E.T. Kovaleva, L.A. Genchikov. Hospital-acquired infection and postoperative complications from the standpoint of the surgeon. Consilium Medicum 0 4. 2000, 2/N General Surgery. Moscow. 2004. (russian)

[6] A.N. Kosinets, Yu.V. Struchkov. Epidemiology and prevention of nosocomial infections. New in the prevention of hospital infection. Inform. bull. Moscow. 1997. P.3-9. (russian)

[7] Process for the production of a gamma-radiation resistant polypropylene fibre for a radiation sterilizable nonwoven fabric [Электронный ресурс]: пат. 0667406 European patent: EP19950300857 19950213/ Makipirtti simo [FI]; Bergholm heikki [FI]; заявитель Suominen Oy J. W. [FI]; заявл. 09.02.96; опубл. 16.08.95.

[8] V.S. Ivanov. Radiation chemistry of polymers [Text]. Publishing house "Chemistry". 1988. 244p. (russian)

[9] I. Ishigaki, F. Yoshii, K. Makuuchi, N. Tamura. Radiation Effects on Polymeric Materials [Электронный pecypc]. Takesaki Radiation Chemistry Research Establishment, Japan Atomic Energy Research Institute.

[10] E.R. Rakhmatullina, R.Y. Galimzyanova, M.S. Lisanevich, Y.N. Khakimullin, O.A. Konovalova. Investigation of the effect of electron radiation on the structure of polypropylene using optical and atomic force spectroscopy methods. Engineering Materials 816 KEM. 2019. P.290-294.

[11] Yu.N. Khakimullin, G.M. Gilmutdinova, A.R. Bakhridinova, M.S. Lisanevich, E. Rakhmatullina, R.Yu. Galimzyanova. Investigation of the influence of non-equilibrium low-temperature plasma on the 

properties of laminated nonwoven fabric. Izvestiya of higher educational institutions. Light industry technology. 2016. Vol.34. No.4. P.68-71. (russian)

[12] Yu.N. Khakimullin, K.V. Legaeva, E.S. Kuznetsova, L.S. Travkina, M.S. Lisanevich, R.Yu. Galimzyanova. The effect of radiation sterilization on the properties of spunlace nonwoven fabric. Bulletin of Kazan Technological University. 2014. Vol.17. No.14. P.150-153. (russian)

[13] Yu.N. Khakimullin, E.R. Rakhmatullina, R.Yu. Galimzyanova, M.S. Lisanevich, I.E. Kogenman, R.S. Yarullin. The possibility of obtaining nonwovens resistant to traditional methods of sterilization in modern production conditions. Bulletin of Kazan Technological University. 2013. Vol.16. No.23. P.118-120. (russian)

[14] L.S. Travkina, M.S. Lisanevich, R.Yu. Galimzyanova, Yu.N. Khakimullin, E.E. Tsareva. Influence of ionizing radiation on the properties of nonwoven materials for medical use. Bulletin of Kazan Technological University. 2013. Vol.16. No.24. P.28-31. (russian)

[15] M.S. Lisanevich, R.Yu. Galimzyanova, N.A. Mukmeneva, Yu.N. Khakimullin, E.R. Rakhmatullina, E.V. Khusnutdinova, D.S. Sirazetdinov, I.I. Garipov. Investigations of the radiation resistance of a block copolymer of propylene and ethylene and the possibility of increasing it. Bulletin of the Technological University. 2018. Vol.21. No.10. P.100-103. (russian)

[16] E.R. Rakhmatullina, M.S. Lisanevich, R.Yu. Galimzyanova, Yu.N. Khakimullin, N.A. Mukmeneva. Influence of processing conditions on the properties of polypropylene. Deformation and destruction of materials. 2017. No.12. P.35-39. (russian)

[17] M.S. Lisanevich, R.Yu. Galimzyanova, N.A. Mukmeneva, Yu.N. Khakimullin, E.R. Rakhmatullina, E.S. Kuznetsova, A.N. Ramazanova. Use of phenolic and mixed phenol-phosphite antioxidants for antiradiation protection of medical polypropylene. Bulletin of the Technological University. 2015. Vol.18. No.2. P.181-182. (russian)

[18] E.R. Rakhmatullina, R.Yu. Galimzyanova, M.S. Lisanevich, E.S. Kuznetsova, Yu.N. Khakimullin, N.A. Mukmeneva. The influence of stabilizers on the properties of medical compositions based on polypropylene. Bulletin of Kazan Technological University. 2013. Vol.16. No.22. P.181-183. (russian)

[19] E.R. Rakhmatullina, R.Yu. Galimzyanova, M.S. Lisanevich, S.M. Khurmatulina, S.A. Fedotov, Yu.N. Khakimullin. Investigation of the effect of nano-additives and mixing time on the properties of compositions based on polypropylene In the collection: Human health in the XXI century IX-th Russian scientific-practical conference: collection of scientific articles. 2017. P.383-387. (russian) 